\title{
Genetic variation in architectural seedling traits of Patagonian cypress natural populations from the extremes of a precipitation range
}

\author{
Mario J. PASTORINO ${ }^{1,2 *}$, Soledad GHIRARdi ${ }^{3}$, Javier GROSFELD ${ }^{1,3}$, Leonardo A. GALlO ${ }^{2}$, \\ Javier G. PUNTIERI ${ }^{1,4}$ \\ ${ }^{1}$ Consejo Nacional de Investigaciones Científicas y Técnicas (CONICET), Argentina \\ ${ }^{2}$ Unidad de Genética Ecológica y Mejoramiento Forestal, Instituto Nacional de Tecnología Agropecuaria (INTA), EEA Bariloche, CC 277, \\ 8400 , S.C. de Bariloche, Argentina \\ ${ }^{3}$ Universidad Nacional del Comahue (UNComa), Centro Regional Universitario Bariloche (CRUB) \\ ${ }^{4}$ Universidad Nacional de Río Negro, Sede Andina, Argentina
}

Keywords: differentiation / phenotypic plasticity /

heritability /

Austrocedrus

(Received 12 June 2009; accepted 17 October 2009)

Mots-clés :

différenciation /

plasticité phénotypique /

héritabilité /

Austrocedrus

\begin{abstract}
- Species distributed along wide environmental ranges are expected to be either plastic or adapted to local optima. The elucidation of which of these alternatives prevails, is crucial in planning breeding and conservation strategies for not yet domesticated species. Austrocedrus chilensis (Cupressaceae) is the most commercially important conifer of the temperate forests of Argentina and the target of a domestication program. A steep precipitation gradient characterizes its Argentinean range.

- Variation within and differentiation among four natural populations of this Patagonian cypress representative of two contrasting precipitation regimes ( $>1300$ and $330 \mathrm{~mm}$ per y) were assessed by analyzing several morpho/architectural traits in one-year-old seedlings grown in a greenhouse.

- Progenies from one of the two xeric populations did not differ from those corresponding to both humid-site populations. The two most variable populations in terms of additive genetic variance belonged to contrasting precipitation regimes. Differentiation among populations was low as measured by each and every variable (average $Q_{s t}=0.088$ ). Morphological traits related to the main axis size would have a dubious adaptive meaning.

- The results suggest that the Patagonian cypress would have not evolved genetic pools adapted to local optima, and thus it appears to be a phenotypically plastic species, at least regarding growth at juvenile age.
\end{abstract}

Résumé - Variation génétique de traits d'architecture de semis de populations naturelles de cyprès de Patagonie provenant des extrêmes de précipitation de son aire naturelle.

- Les espèces presentant de vastes aires de répartition avec des fortes variations de l'environnement sont soit plastiques, soit adaptées à des optima locaux. Identifier laquelle de ces deux alternatives est celle qui prévaut est une étape cruciale pour planifier des stratégies d'amélioration génétique ou de conservation d'espèces non encore domestiquées. Austrocedrus chilensis (Cupressaceae) est le conifère le plus important du point de vue commercial dans les forêts tempérées d'Argentine et fait l'object d'un programme de domestication. Un fort gradient de précipitations caractérise son aire de répartition en Argentine.

- Les variations intra-population et la différenciation entre quatre populations naturelles représentatives de deux régimes contrastés de précipitations (>1300 $\mathrm{mm}$ et $330 \mathrm{~mm}$ par an) ont été évaluées en analysant plusieurs traits d'architecture et de morphologie sur des plants âgés de un an cultivés sous serre.

- Les descendants de l'une des deux populations xériques ne différaient pas de ceux des deux populations de sites humides. Les deux populations avec la plus forte variance génétique additive provenaient de régimes contrastés de précipitation. La différenciation entre populations était faible tant pour chaque trait que pour l'ensemble des traits $\left(Q_{s t}=0.088\right)$. Les caractéristiques morphologiques liées à la taille de l'axe principal n'auraient donc que peu signification en termes d'adaptation.

\footnotetext{
*Corresponding author: mpastorino@bariloche.inta.gov.ar
} 
- Les résultats suggèrent que le cyprès de Patagonie n'aurait pas développé de pools génétiques adaptés aux optima locaux. Il semble être une espèce phénotypiquement plastique, au moins en ce qui concerne la croissance au stade juvénile.

\section{INTRODUCTION}

Species distributed along wide environmental ranges are expected to be either plastic or adapted to local optima. Plasticity implies that a common gene pool shared among populations is capable of acclimation, producing different phenotypes in each environment (Via and Lande, 1987). On the contrary, adaptation means that a specialized gene pool is present in each particular ecological condition, what leads to genetic differentiation. The elucidation of which of these alternatives prevails, is crucial in planning breeding and conservation strategies for not yet domesticated species.

The Instituto Nacional de Tecnología Agropecuaria, INTA, (San Carlos de Bariloche, Argentina) is currently engaged in a domestication program for Patagonian cypress (Austrocedrus chilensis (D. Don) Pic. Ser. et Bizzarri, Cupressaceae). This Argentinean and Chilean conifer presents a valuable breeding potential and is also an important target for conservation since, besides its ecological relevance, it has been classified as a vulnerable species by the IUCN (Conifer Specialist Group, 1998). The most prominent environmental range of its distribution area in the Argentinean side of the Andes Mountains is a steep West-to-East decreasing precipitation gradient. Natural populations of Patagonian Cypress can be found in sites ranging in annual precipitation between less than 400 and more than $2000 \mathrm{~mm}$ (Gallo et al., 2004). This wide range for a truly relevant environmental variable gives the possibility of testing whether acclimation or adaptation is the main strategy of this species to survive in a so heterogeneous region.

These alternative scenarios may be tested by means of classic common garden trials: if differentiation is true, phenotypic differences among provenances will arise under common environmental conditions. Sampling a set of natural populations gradually following the precipitation range would help to test clinal variation. However, when the study is aimed at identifying whether differentiation or plasticity takes place, sampling the extremes of the gradient may provide enough more conclusive and certainly simpler evidence.

In nature, the earliest stages of plant development are the most susceptible to selection processes (King, 1990; Moles and Westoby, 2004; Seiwa and Kikuzawa, 1991). Thus, differences in seedling traits would be expected if adaptation has indeed occurred. Seedlings adapted to drought stress would present morphological adjustments related to a more conservative development, with a significantly smaller above-ground size (Cregg, 1994).

The Patagonian Cypress was the subject of previous genetic studies, which constitute valuable antecedents. However, all of them were based on selectively neutral gene markers. Studies performed with isozymes have shown that the allelic frequencies do not differ greatly among natural populations of this species, irrespective of the distances and environmental differences among them (Pastorino and Gallo 2002; Pastorino et al., 2004). Neutral differentiation among 27 populations representing the whole Argentinean range of the species resulted low (Pastorino and Gallo, 2009). This pattern was explained in relation with the post-glacial life history of the species. However, contrasting environments, which are irrelevant for selectively neutral markers, are expected to have an influence on adaptive traits instead. Our main hypothesis is, therefore, that contrasting precipitation regimes significantly affect the genetic variation pattern of susceptible-to-selection traits. The corresponding predictions are: (1) differentiation calculated for seedlings' morpho/architectural traits will be large among populations developed under contrasting precipitation regimes; (2) intra-population genetic variation will be lower in those populations undergone stronger selective pressure, namely in those suffering drought stress; and (3) populations growing under a similar precipitation regime but genetically isolated from each other (without gene-flow between them), will present no significant differences in adaptive traits.

\section{MATERIALS AND METHODS}

\subsection{Plant material}

The variation in morphological traits measured on one-year-old seedlings originating from four natural populations of Austrocedrus chilensis was analyzed in a common garden trial.

Populations were selected in order to represent contrasting precipitation regimes within the species' Argentinean range (Tab. I and Fig. 1). More than $1000 \mathrm{~mm}$ of annual precipitation differentiate both sampled conditions. Two populations separated by more than $100 \mathrm{~km}$ represented humid sites: Río Azul and Cerro Catedral. Río Azul is a continuous and compact forest with cypresses taller than 25 m mixed with Nothofagus dombeyi (Mirb.) Oerst., and other secondary species. Cerro Catedral is also a mixed forest but slightly more open and with shorter cypresses (up to $20 \mathrm{~m}$ high). Low precipitation sites were represented by two neighbouring populations, Pilcañeu North and Pilcañeu South, situated at the top of two rocky hills in the steppe and distant only $1200 \mathrm{~m}$ from each other. These two small stands (with about one-hundred adult individuals each) are the xeric extreme of the species range. Trees are 4 to $6 \mathrm{~m}$ tall, with tortuous shape and scattered over some 4 ha in each population. No other tree species accompany these Patagonian cypresses. In a previous work based on neutral markers (Pastorino and Gallo, 2009), these two populations were shown to be genetically quite distant in spite of their geographic proximity. A hindered gene flow between them was inferred by means of isozymes, what is probably caused by their relative position perpendicular to the predominant and strong westerly winds.

In each of the four populations, cones were collected directly from the tree crowns, keeping a minimum distance of $30 \mathrm{~m}$ between trees in order to reduce the probability of sampling related individuals. 
Table I. Location and mean annual precipitation (m.a.p.) of the four sampled Austrocedrus chilensis populations.

\begin{tabular}{lcccc}
\hline Population & $\begin{array}{c}\text { Latitude } \\
\mathrm{S}\end{array}$ & $\begin{array}{c}\text { Longitude } \\
\mathrm{W}\end{array}$ & $\begin{array}{c}\text { Altitude } \\
\text { (m a.s.1.) }\end{array}$ & $\begin{array}{c}\text { m.a.p. } \\
(\mathrm{mm})\end{array}$ \\
\hline Río Azul & $42^{\circ} 06^{\prime}$ & $71^{\circ} 40^{\prime}$ & 300 & 1.600 \\
Cerro Catedral & $41^{\circ} 08^{\prime}$ & $71^{\circ} 27^{\prime}$ & 850 & 1.350 \\
Pilcañeu North & $41^{\circ} 13^{\prime}$ & $70^{\circ} 42^{\prime}$ & 1.100 & 330 \\
Pilcañeu South & $41^{\circ} 14^{\prime}$ & $70^{\circ} 41^{\prime}$ & 1.100 & 330 \\
\hline
\end{tabular}

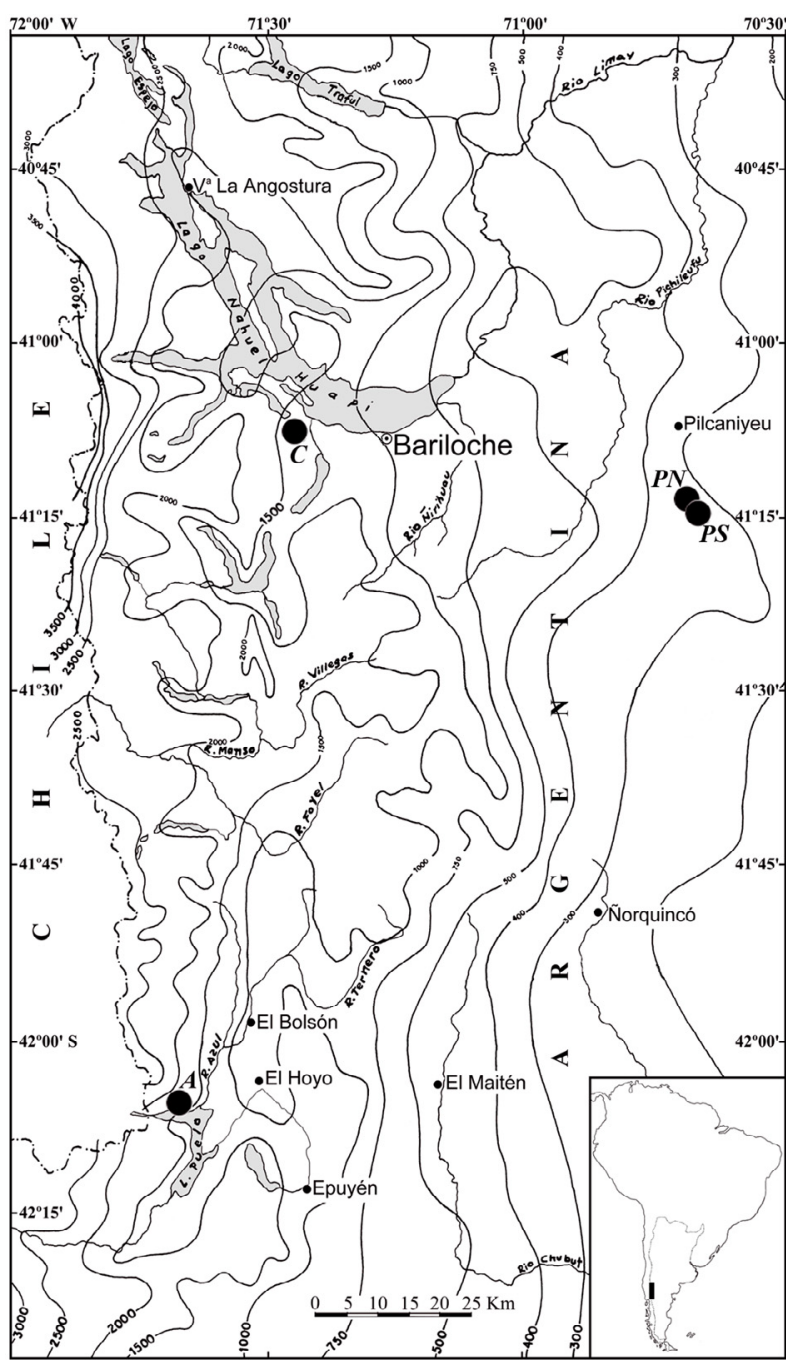

Figure 1. Sampled populations of Austrocedrus chilensis over an isohyet map (from Cordon et al., 1993). A: Río Azul; C: Cerro Catedral; PN: Pilcañeu North, and PS: Pilcañeu South.

\subsection{Experimental design}

Seeds were extracted from the cones and sown in flats at the beginning of spring following a pre-germination treatment. Immediately after germination, a sample of seedlings was transplanted to single $265 \mathrm{~cm}^{3}$ pots of square section and $15 \mathrm{~cm}$ depth $\left(\mathrm{HIKO}^{\mathrm{TM}} \mathrm{HV} 265\right.$ tray type), and ordered according to a totally balanced experimental design.
For each of the four populations, seven open-pollinated families were represented by 30 seedlings each, distributed in three blocks (sub-sampling experimental design, with 10 seedlings per block distributed in two adjacent five-seedling rows; i.e. 210 seedlings per population). The trial was located in a greenhouse under controlled conditions without water limitations (i.e. temperature between $10{ }^{\circ} \mathrm{C}$ and $25{ }^{\circ} \mathrm{C}, 1: 1$ peat-sand substrate and ferti-irrigation with an N-P$\mathrm{K}+$ micronutrients diet adjusted for the species) at San Carlos de Bariloche city ( $41^{\circ} 07^{\prime} \mathrm{S}$ lat., $71^{\circ} 15^{\prime} \mathrm{W}$ long., $810 \mathrm{~m}$ a.s.1.).

\subsection{Variables measured}

For each seedling, five primary variables were measured in winter after the first growing season: basal diameter of the main axis $(A D)$, measured immediately above the cotyledons; main axis length $(A L)$, measured from the cotyledons to the apical bud; number of nodes $(N N)$, excluding the cotyledonary node; number of branches of the main axis $(N B)$; and the length of the most basal branch $(B L)$. These five variables are mainly indicative of growth vigour. Lengths and diameters were measured with a digital calliper to the nearest $0.1 \mathrm{~mm}$.

Three additional variables were derived from the previous ones: mean internode length $(A L / N N)$; the ratio between main axis length and basal diameter $(A L / A D)$ which measures stem slenderness; and the ratio between the lengths of the basal branch and the main axis $(B L / A L)$, which evaluates the relative branch development of the seedling and is a sign of the dominance of the main axis on the major branch. These three secondary variables are mainly related to architectural balances of the aerial portion of each seedling.

\subsection{Statistical analyses}

In order to test the statistical significance of differences among populations and the variability among families, an ANOVA test was performed for each of the considered variables under the following mixed nested model with independent and normally distributed residuals:

$$
y_{i j k l}=\mu+\rho_{i}+\beta_{j}+\varphi_{k}\left(\rho_{i}\right)+e_{i j k}+\varepsilon_{i j k l}
$$

where $y_{i j k l}$ is an observation of the variable for the $l$ th seedling, from the $k$ th family within the $i$ th population located in the $j$ th block; $\mu$ is the overall mean for the variable; $\rho_{i}$ is the effect (fixed) of the $i$ th population; $\beta_{j}$ is the effect (random) of the $j$ th block; $\phi_{k}\left(\rho_{i}\right)$ is the effect (random) of the $k$ th family within the $i$ th population; $e_{i j k}$ is the main plot error $\operatorname{NID}\left(0, \sigma_{e}^{2}\right)$, and $\varepsilon_{i j k l}$ is the sub-sampling residual $N I D\left(0, \sigma_{\varepsilon}^{2}\right)$.

Tests were performed through the GLM procedure (type III sums of squares) of the SAS software (1989), and components of variance were obtained by restricted maximum likelihood with the MIXED 
procedure of SAS. The algorithm of the MIXED procedure gives exactly the same result as the VARCOMP procedure due to data balance. Normality of the data was assessed by a histogram and a normal probability plot of the residuals and a Shapiro-Wilk test (Sokal and Rohlf, 1995) for each variable. Homocedasticity was checked by plotting the residuals against the predicted values. In order to compare all possible population pairs through the means, Tukey tests were performed ( $\alpha=0.05$; SAS, 1989). Bar graphics were drawn with the help of R 2.8.1 (R Development Core Team, 2008).

\subsection{Intra-population genetic parameters}

Additive genetic variance is the basic parameter to estimate genetic variation within a population. In open-pollinated families, relationships among their members are expected to be closer than those among members of true half-sib families, but not as close as those of full sibs. Since A. chilensis is a dioecious species, selfing is not possible. Nonetheless, individuals were shown to mate not randomly but in groups (Pastorino and Gallo, 2006). Consequently, the additive genetic variance was estimated as three times the family variance, namely an intermediate factor between 4 and 2, corresponding to half and full sibs respectively (Squillace, 1974):

$$
\sigma_{A}^{2}=3 \cdot \sigma_{f}^{2}
$$

where $\sigma_{A}^{2}$ is the additive genetic variance and $\sigma_{f}^{2}$ is the family variance.

Since additive genetic variance values are a function of the units used, an additive genetic coefficient of variation $\left(C V_{A}\right.$; Houle, 1992) was calculated so as to render direct comparisons among variables meaningful:

$$
C V_{A}=100 \frac{\sqrt{\sigma_{A}^{2}}}{x}=100 \frac{\sqrt{3 \cdot \sigma_{f}^{2}}}{x}
$$

where $x$ is the variable mean.

Narrow-sense heritabilities $\left(h^{2}\right)$ were calculated for each variable taking each population separately and also pooling the data across populations, according to the equation:

$$
h^{2}=\frac{\sigma_{A}^{2}}{\sigma_{P}^{2}}=\frac{3 \cdot \sigma_{f}^{2}}{\sigma_{f}^{2}+\sigma_{b}^{2}+\sigma_{e}^{2}}
$$

where $\sigma_{P}^{2}$ is the phenotypic variance, $\sigma_{b}^{2}$ is the block variance, and $\sigma_{e}^{2}$ is the error variance, which is the sum of the variances of the main plot and the sub-sampling residuals.

The standard error $(S E)$ of the heritability was also calculated with factor 3:

$$
S E_{h^{2}}=3 \cdot \sqrt{\frac{2 \cdot\left[1+(n-1) \cdot h^{2} / 3\right]^{2} \cdot\left(1-h^{2} / 3\right)^{2}}{n \cdot(n-1) \cdot(f-1)}}
$$

where $f$ is the number of families and $n$ is the number of individuals within each family (Falconer and Mackay, 1996).

Phenotypic and additive genetic correlations (Pearson's correlation coefficient $r_{P}$ and $r_{A}$ respectively) were calculated for the four populations as a pool for all the possible combinations of primary variables according to the formulae:

$$
r_{P}=\frac{\operatorname{Cov}_{x y}}{\sqrt{\sigma_{x}^{2} \cdot \sigma_{y}^{2}}} \text { and } r_{A}=\frac{\operatorname{Cov}_{f_{x y}}}{\sqrt{\sigma_{f_{x}}^{2} \cdot \sigma_{f_{y}}^{2}}}
$$

where $\operatorname{Cov}_{x y}$ is the covariance between variables $x$ and $y, \sigma_{x}^{2}$ and $\sigma_{y}^{2}$ are the variances of both variables, $\sigma_{f x}^{2}$ and $\sigma_{f y}^{2}$ are the family variances of the variables, and $\operatorname{Cov}_{f x y}$ is the family covariance of the variables, which is calculated by

$$
\operatorname{Cov}_{f_{x y}}=\frac{\sigma_{f_{x+y}}^{2}-\sigma_{f_{x}}^{2}-\sigma_{f_{y}}^{2}}{2}
$$

where $\sigma_{f x+y}^{2}$ is the family variance of a variable built by the sum of both variables (O'Neill et al., 2001).

Standard errors of phenotypic and genetic correlations were computed by

$$
S E_{r_{P}}=\sqrt{\frac{1-r_{P}^{2}}{N-2}} \text { and } S E_{r_{A}}=\sqrt{\frac{\left(1-r_{A}^{2}\right)^{2}}{f-1}}
$$

where $N$ is the total number of individuals sampled (Visscher, 1998).

\subsection{Inter-population genetic parameters}

Partitioning the phenotypic variance of each variable into its components, and particularly distinguishing within- and amongpopulations components lead to a straightforward calculation of genetic differentiation among populations for quantitative traits, $Q_{s t}$ (Spitze, 1993), for each variable by means of:

$$
Q_{s t}=\frac{\sigma_{\text {pop }}^{2}}{\sigma_{\text {pop }}^{2}+2\left(3 \sigma_{f}^{2}\right)}
$$

where $\sigma_{\text {pop }}^{2}$ is the variance among populations calculated after considering the original model but with populations as a random effect factor.

\section{RESULTS}

\subsection{Comparisons among populations through phenotypic values}

The plants from the xeric population Pilcañeu South were, on average, the least vigorous as revealed by the mean values of all five primary variables. The most vigorous seedlings, according to these variables, were those of Cerro Catedral and Río Azul (Fig. 2).

Significant differences among populations were revealed by means of ANOVA tests for phenotypic values of all traits but axis length $(A L)$, internode length $(A L / N N)$ and the ratio between axis length and basal diameter $(A L / A D)$ (Tab. II). Tukey tests showed no differences between Río Azul and Cerro Catedral, and between Pilcañeu North and Pilcañeu South in the phenotypic values of all variables. Pilcañeu North could not be differentiated from the humid populations (it showed significant differences with Cerro Catedral only regarding the number of branches; Fig. 2).

Variability among families was shown to be significant for all primary and secondary variables. The block factor was not significant in all but two secondary variables (Tab. II). 


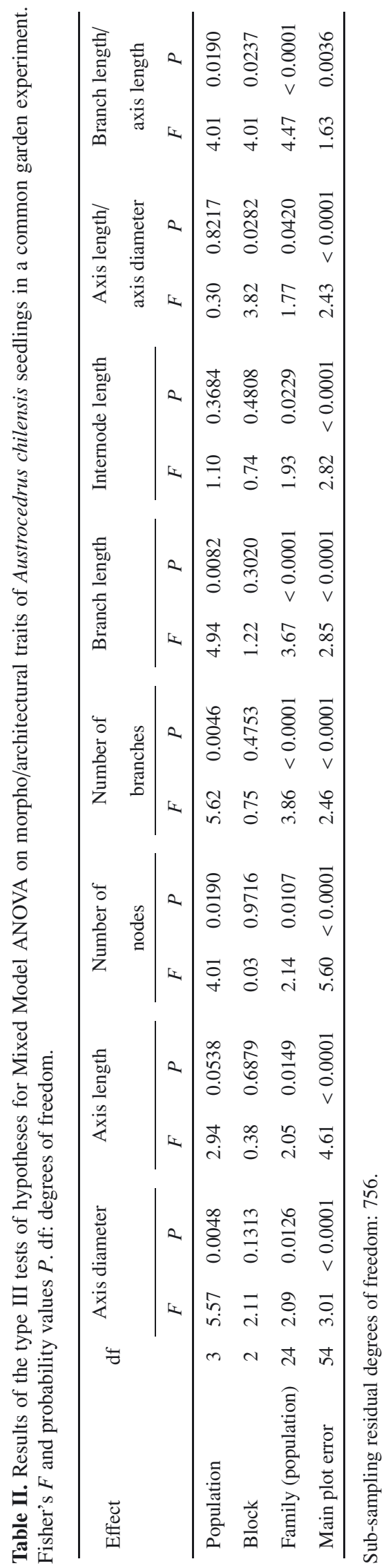



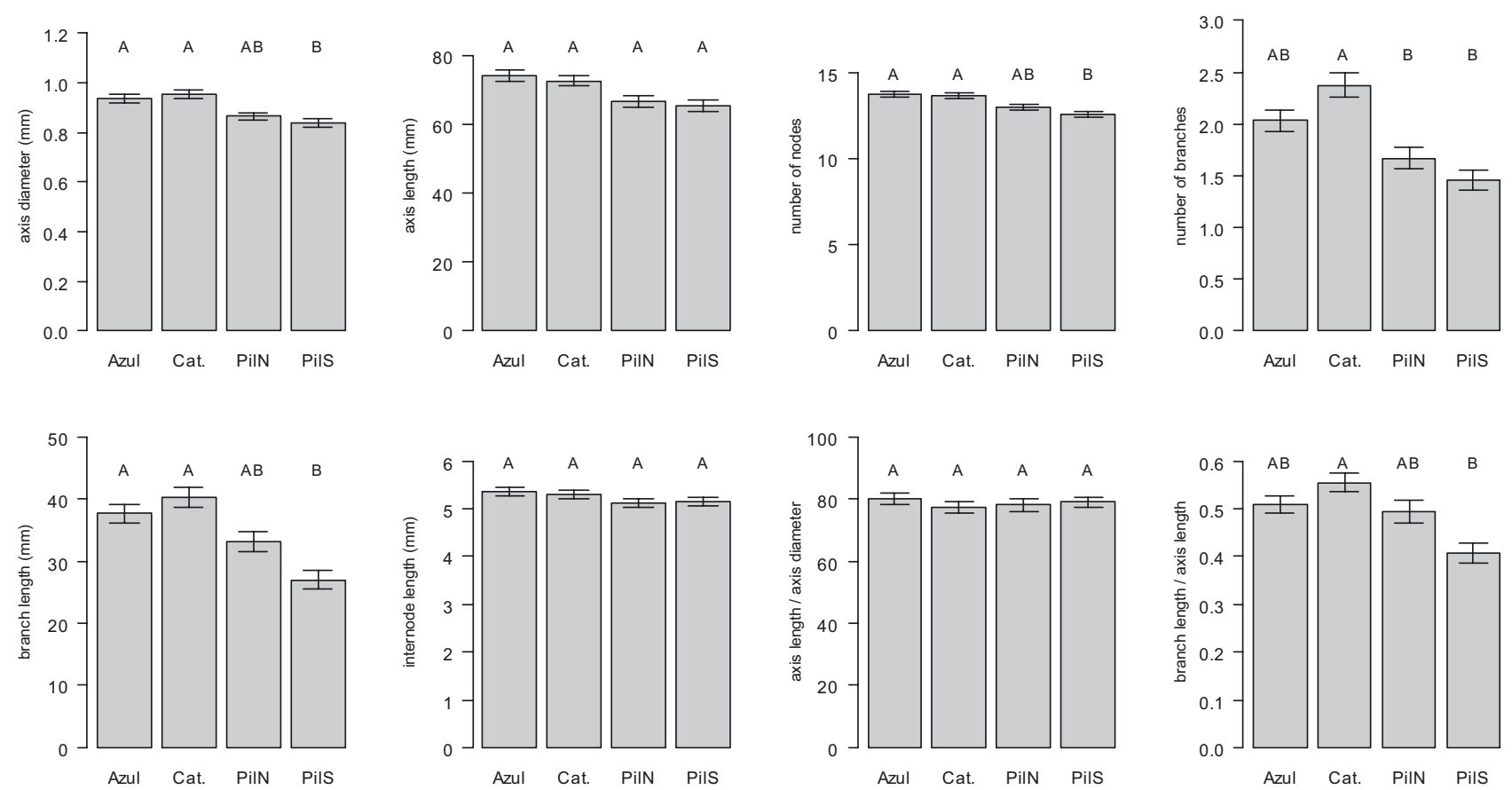

Figure 2. Means and confidence intervals $(\alpha=0.05)$ for eight seedling traits in four natural populations of Austrocedrus chilensis: Río Azul (Azul), Cerro Catedral (Cat.), Pilcañeu North (PilN) and Pilcañeu South (PilS). Different letters indicate significant differences (pairwise Tukey tests).

\subsection{Intra-population genetic variation}

From the values of additive genetic coefficient of variation, but especially from those of additive genetic variance $\left(\sigma_{A}^{2}\right)$, it becomes evident that Pilcañeu South was the least variable population whereas Río Azul and Pilcañeu North were the most variable populations in almost all of the traits (Tab. III).

All primary variables were moderately to highly positively correlated (all $r_{P}$ and $r_{A}$ were higher than 0.4, Tab. IV). Pearson phenotypic correlations were all significant $(P<0.001)$, with additive genetic correlations higher than phenotypic correlations in all cases but $N N$ vs. $N B$. The highest genetic correlations were those between: $A L$ and $A D, B L$ and $N B$, and $A L$ and $N N\left(r_{A}>0.9\right)$, while the lowest correlation was that between $N B$ and $N N$ (Tab. IV). The estimated phenotypic correlation between $A D$ and $A L$ was among the lowest correlations. The highest phenotypic correlations were those between $B L$ and $N B$ and between $A L$ and $N N\left(r_{P}>0.71\right.$; Tab. IV).

\subsection{Heritability}

Single-population heritabilities were quite variable among populations, with the lowest values in Pilcañeu South for all traits, and the highest in Río Azul or eventually in Pilcañeu North (Tab. III).

Besides single-population heritabilities, a value of narrow sense heritability was calculated for a hypothetic population built by pooling the 28 families corresponding to the four populations surveyed. This procedure allows to better extract a measure of the genetic control for each trait, since the calculation of this pooled heritability is more accurate (lower standard errors) due to the larger sampling. According to this, the traits with the highest genetic control were $B L\left(h^{2}=0.53\right)$ and $N B\left(h^{2}=0.51\right)$. In general terms, all the primary variables presented a moderate to high heritability. The lowest pooled heritability corresponded to the $A L / A D$ ratio $\left(h_{A L / A D}^{2}=0.15\right.$; Tab. III).

\subsection{Genetic differentiation}

The mean differentiation calculated for all five primary variables was $Q_{s t}=0.122$, and that for all primary and secondary variables 0.088 . The $Q_{s t}$ calculated for the $A L / A D$ ratio was 0 . This result was caused by a null component of variance of the factor "population", that is, seedlings belonging to different populations were as different among them (with respect to this variable) as those belonging to the same population. The highest differentiation corresponded to $A D\left(Q_{s t}=0.172\right.$; Tab. III $)$, which could be considered moderate.

\section{DISCUSSION}

\subsection{Phenotypic differences among populations}

The results of this trial showed that Patagonian Cypress seedlings whose parent trees belonged to populations growing under similar precipitation levels (namely, Río Azul - Cerro 
Table III. Additive genetic variance $\left(\sigma_{A}^{2}\right)$, additive genetic coefficient of variation $\left(C V_{A}\right)$ and heritability $\left(h^{2}\right)$ for eight variables measured in Austrocedrus chilensis seedlings from four natural populations. Heritabilities for the pooled populations and genetic differentiation between them $\left(Q_{s t}\right)$ are indicated for each variable in the right columns. Standard errors $(S E)$ are shown between brackets. $A D$ : main axis basal diameter, $A L$ : main axis length, $N N$ : number of nodes, $N B$ : number of branches, $B L$ : basal branch length.

\begin{tabular}{|c|c|c|c|c|c|c|c|}
\hline & & Río Azul & Cerro Catedral & Pilcañeu North & Pilcañeu South & $h^{2}(S E)$ & $\overline{Q_{s t}}$ \\
\hline \multirow{3}{*}{$\begin{array}{l}A D \\
(\mathrm{~mm})\end{array}$} & $\overline{\sigma_{A}^{2}}$ & 0.015 & 0.004 & 0.008 & 0.0001 & \multirow{3}{*}{$0.25(0.086)$} & \multirow{3}{*}{0.1724} \\
\hline & $C V_{A}^{A} \%$ & 13.2 & 6.7 & 10.6 & 1.2 & & \\
\hline & $h^{2}(S E)$ & $0.56(0.307)$ & $0.15(0.135)$ & $0.42(0.255)$ & $0.004(0.061)$ & & \\
\hline \multirow{3}{*}{$\begin{array}{l}A L \\
(\mathrm{~mm})\end{array}$} & $\overline{\sigma_{A}^{2}}$ & 131.910 & 47.501 & 102.652 & 31.248 & \multirow{3}{*}{$0.32(0.101)$} & \multirow{3}{*}{0.0810} \\
\hline & $C V_{A}^{A} \%$ & 15.5 & 9.5 & 15.2 & 8.6 & & \\
\hline & $h^{2}(S E)$ & $0.55(0.302)$ & $0.25(0.184)$ & $0.50(0.285)$ & $0.15(0.135)$ & & \\
\hline \multirow{3}{*}{$N N$} & $\sigma_{A}^{2}$ & 1.555 & 0.765 & 1.755 & 0.049 & \multirow{3}{*}{$0.38(0.114)$} & \multirow{3}{*}{0.1157} \\
\hline & $C V_{A}^{A} \%$ & 9.1 & 6.4 & 10.2 & 1.8 & & \\
\hline & $h^{2}(S E)$ & $0.83(0.383)$ & $0.32(0.215)$ & $0.80(0.377)$ & $0.02(0.070)$ & & \\
\hline \multirow{3}{*}{$N B$} & $\overline{\sigma_{A}^{2}}$ & 0.784 & 0.346 & 0.669 & 0.187 & \multirow{3}{*}{$0.51(0.136)$} & \multirow{3}{*}{0.1290} \\
\hline & $C V_{A}^{A} \%$ & 43.6 & 24.8 & 49.1 & 29.7 & & \\
\hline & $h^{2}(S E)$ & $0.84(0.386)$ & $0.32(0.213)$ & $0.77(0.368)$ & $0.27(0.191)$ & & \\
\hline \multirow{3}{*}{$\begin{array}{l}B L \\
(\mathrm{~mm})\end{array}$} & $\overline{\sigma_{A}^{2}}$ & 202.632 & 90.351 & 112.338 & 66.181 & \multirow{3}{*}{$0.53(0.139)$} & \multirow{3}{*}{0.1142} \\
\hline & $C V_{A}^{A} \%$ & 37.8 & 23.5 & 32.0 & 30.1 & & \\
\hline & $h^{2}(S E)$ & $1.02(0.421)$ & $0.42(0.257)$ & $0.54(0.298)$ & $0.33(0.220)$ & & \\
\hline \multirow{3}{*}{$\begin{array}{l}A L / N N \\
(\mathrm{~mm})\end{array}$} & $\overline{\sigma_{A}^{2}}$ & 0.159 & 0.104 & 0.199 & 0.090 & \multirow{3}{*}{$0.21(0.077)$} & \multirow{3}{*}{0.0049} \\
\hline & $C V_{A}^{A} \%$ & 7.4 & 6.1 & 8.7 & 5.8 & & \\
\hline & $h^{2}(S E)$ & $0.23(0.175)$ & $0.16(0.143)$ & $0.30(0.207)$ & $0.14(0.131)$ & & \\
\hline \multirow{3}{*}{$A L / A D$} & $\overline{\sigma_{A}^{2}}$ & 0.857 & 56.570 & 105.616 & 0 & \multirow{3}{*}{$0.15(0.065)$} & \multirow{3}{*}{0} \\
\hline & $C V_{A}^{A} \%$ & 1.2 & 9.7 & 13.2 & 0 & & \\
\hline & $h^{2}(S E)$ & $0.003(0.061)$ & $0.24(0.179)$ & $0.36(0.233)$ & $0(0.059)$ & & \\
\hline \multirow{3}{*}{$B L / A L$} & $\overline{\sigma_{A}^{2}}$ & 0.016 & 0.014 & 0.025 & 0.011 & \multirow{3}{*}{$0.45(0.125)$} & \multirow{3}{*}{0.0846} \\
\hline & $C V_{A}^{A} \%$ & 24.6 & 21.4 & 32.0 & 25.5 & & \\
\hline & $h^{2}(S E)$ & $0.59(0.317)$ & $0.44(0.262)$ & $0.56(0.306)$ & $0.28(0.199)$ & & \\
\hline
\end{tabular}

Table IV. Phenotypic (above diagonal) and genetic (below diagonal) correlations between five morpho/architectural traits of Austrocedrus chilensis seedlings and their standard errors (between brackets).

\begin{tabular}{lccccc}
\hline & $\begin{array}{c}\text { Basal } \\
\text { diameter } \\
(A D)\end{array}$ & $\begin{array}{c}\text { Axis } \\
\text { length } \\
(A L)\end{array}$ & $\begin{array}{c}\text { Number of } \\
\text { nodes } \\
(N N)\end{array}$ & $\begin{array}{c}\text { Number of } \\
\text { branches } \\
(N B)\end{array}$ & $\begin{array}{c}\text { Branch } \\
\text { length } \\
(B L)\end{array}$ \\
\hline$A D$ & & $0.48(0.030)$ & $0.50(0.030)$ & $0.54(0.029)$ & $0.59(0.028)$ \\
$A L$ & $1.83(0.453)$ & & $0.71(0.024)$ & $0.48(0.030)$ & $0.57(0.028)$ \\
$N N$ & $0.61(0.122)$ & $0.96(0.016)$ & & $0.55(0.029)$ & $0.58(0.028)$ \\
$N B$ & $0.67(0.107)$ & $0.66(0.107)$ & $0.46(0.152)$ & & $0.81(0.020)$ \\
$B L$ & $0.82(0.063)$ & $0.79(0.073)$ & $0.66(0.109)$ & $0.96(0.016)$ & \\
\hline
\end{tabular}

Catedral and Pilcañeu North - Pilcañeu South) did not differ regarding phenotypic values of morphological and architectural traits. However, seedlings of one of the xeric populations (Pilcañeu North) did not differ from those of the humid populations either. Thus, the precipitation regime would not be a selective pressure determining seedling morphology and architecture, at least for the traits considered in the present study. Working on a sample of only five seedlings per provenance, Gyenge et al. (2005) consistently found no differences among populations of $A$. chilensis with contrasting precipitation levels regarding several physiological parameters (photosynthetic and stomatal responses to drought, leaf water content, hydraulic resistance and xylem cavitation vulnerability).
The length of the main axis is determined by the number of nodes and internodes produced on the axis and, most importantly, by the degree of extension of its internodes. It has been pointed out that internode extension in plant axes is more dependent upon microenvironmental conditions than the number of nodes, which would be more closely tied to endogenous regulation (Puntieri et al., 1998). Consistently, it has been suggested that early height growth would lack adaptive value in stress-tolerant conifers (López et al., 2007). This seems to be the case in Patagonian Cypress, since the sampled populations differed regarding the number of nodes of the main axis but not internode length which, in turn, brought about non-significant differences in height. Differences between populations in 
height growth have been shown to increase with plant age, especially in conifers (e.g. Foster, 1986; Namkoong and Conkle, 1976; Namkoong et al., 1972). Thus, differences among $A$. chilensis populations regarding plant height cannot be dismissed to become significant in further years.

\subsection{Genetic variation and correlations}

Additive genetic variances of all traits but the main axis slenderness were highest for Río Azul and Pilcañeu North populations, intermediate for Cerro Catedral, and lowest for Pilcañeu South. It can be seen in general that the two most variable populations (with similar levels of variation) belong to sites with contrasting precipitation regimes. This is again supporting that the precipitation level does not represent a strong selective force for the surveyed variables. Otherwise, humid and the xeric populations would have been clearly differing in terms of genetic variation (considering that those traits under strong selective pressure would present the lowest levels of variation; Reich et al., 2003). In other words, the lack of adaptive value of the considered traits in regard to the precipitation condition might be postulated. In that respect, we should distinguish two types of traits among those considered here: traits concerning main axis development, and traits concerning branch development. The former presented lower additive genetic coefficients of variation in the four populations, and lower single population and pooled heritabilities. These are evidences of lower adaptive value.

We can search further evidence by comparing populations with the same precipitation regime. As mentioned above, Pilcañeu South is the least genetically variable population in terms of $\sigma_{A}^{2}$ for all traits. However, its neighbouring population, Pilcañeu North, exhibited the opposite pattern. This difference between the two xeric populations does not match an adaptation process. This is especially true for the main axis traits, for which the differences in terms of $C V_{A}$ between both populations are the largest. Since both populations are quite small, genetic drift appears to have been a reasonable cause of such differences, together with the already mentioned hindered gene flow.

The estimations of heritability in the Pilcañeu South population can also help to distinguish two types of traits. Basal diameter, number of nodes and main axis slenderness presented heritabilities close to zero for Pilcañeu South, even though they exhibited moderate to high heritabilities for the other populations. On the other hand, basal branch length, number of branches and the branch-length/main-axis-length ratio for Pilcañeu South population had moderate heritabilities, closer to those of the other populations.

In the present study, the genetic correlation between main axis basal diameter and main axis length surpassed the highest theoretical value of 1 . This is a hardly reported but not uncommon result. It must be taken into account when assessing these correlations that they are estimations of the true correlations in which additive epistatic interactions are potentially included in the estimates of the genetic variances and covariances (Lynch and Walsh, 1998). The large standard error of the mentioned correlation (0.453) indicates that the true correlation lies within a confidence interval that includes the value 1 . In any case, it is clear that height and basal diameter are closely tied at this early growth stage.

The low number of families per population in our trial does not allow for an analysis of correlations within each population, so that the calculated values should be taken as indicative. However, a general trend is evident, since additive genetic correlations were higher than phenotypic correlations in almost all cases. This means a low environmental correlation and renders more support for combining these surveyed traits as early selecting criteria. For example, the relatively high genetic control of branch development may be beneficial for an early selection of seedlings, what could be performed either by the number of branches or the length of the basal branch because these traits are highly correlated (both phenotypically and genetically).

\subsection{Differentiation}

$F_{s t}$ (Wright, 1978) is a differentiation parameter analogous to $Q_{s t}$ but especially designed for neutral markers. Their conceptual analogy makes them possible to be compared in a direct way, thus allowing to understand the role played by selection and other evolutionary forces in modeling the partition of the genetic variation among and within populations (McKay and Latta, 2002; Merilä and Crnokrak, 2001).

Differentiation among 27 natural populations of A. chilensis measured by means of isozyme markers was $F_{s t}=0.060$ (Pastorino and Gallo, 2009). Although the present study is not based on those 27 populations, this $F_{s t}$ value can be taken as a reference. Comprehensive reviews have demonstrated that, on average, $Q_{s t}$ is typically higher than $F_{s t}$ (Leinonen et al., 2008; McKay and Latta, 2002; Merilä and Crnokrak, 2001).

According to a scale proposed by Bower and Aitken (2008), in our results the differentiation among populations resulted low for all variables, but especially for the secondary ones. We can further distinguish three ranges of $Q_{s t}$ values: very low $\left(Q_{s t}<1 \%\right)$, low $\left(8 \%<Q_{s t}<13 \%\right)$ and moderate $\left(Q_{s t}=17 \%\right)$. For the traits with very low $Q_{s t}$ values, which are clearly below the $F_{s t}$. value reported, we should presume that natural selection has favoured the same mean phenotype in different populations. On the other extreme, we could deduce directional natural selection favouring different basal diameter phenotypes in different populations, since $Q_{s t A D}>F_{s t}$ (Merilä and Crnokrak, 2001). However, our calculated mean quantitative differentiation $\left(Q_{s t}=0.088\right)$ was not much higher than the reported $F_{s t}$, but in fact quite similar. This similarity does not evidence a selection process; instead, the observed quantitative differentiation can be simply explained by genetic drift and restricted gene flow, particularly considering that the populations sampled represent quite contrasting environments.

In some species of the Cupressaceae family, the development of branches in terms of number, angle and size compared to that of the trunk, is considered to be relevant in distinguishing taxonomical varieties (Grosfeld, 2002; Grosfeld and 
Barthélémy, 2004). If, as discussed above, we distinguish between the two types of traits in A. chilensis, we have a mean $Q_{s t}$ for main axis traits of 0.075 and a mean $Q_{s t}$ for branch traits of 0.109 . This difference is in accordance with the expectation. However, differentiation based on neutral markers seems not so different from differentiation based on quantitative traits, especially those of the main axis.

Basal diameter was the trait that most differentiated the four populations. In contrast, main axis length, another trait indicative of aerial vigour, was the least discriminating primary variable. Coincidently, this variable measured in two similar trials on Pinus sylvestris L. and Ulmus laevis Pall. provided similar results $\left(Q_{s t \mathrm{ALPs}}=0.08\right.$, Notivol et al., 2007; $Q_{s t \mathrm{ALUl}}=0.077$, Whiteley et al., 2003). These results further support the idea of low adaptive value of main axis length.

The generally low differentiation among A. chilensis populations found in the present study might be due to the early ontogenic stage on which this type of traits was assessed (Cavender-Bares and Bazzaz, 2000). The contrasting environments of the populations sampled may indeed be acting as selective forces but over traits directly related to hydraulic balances and tolerance to drought stress. Higher differentiation among these populations might be found by analysing the traits of underground tissues or physiological mechanisms conditioning the water economy (carbon isotope discrimination, $\delta^{13} \mathrm{C}$, is a good alternative for genetic studies with hundreds of individuals, as shown by Lauteri et al., 2004).

\subsection{Concluding remarks}

The results gave not support for our three original predictions: (1) differentiation was low; (2) intra-population genetic variation was not the lowest in the two most stressed populations and (3) populations growing under a similar precipitation regime showed no significant differences in their seedlings' traits but populations growing under contrasting precipitation regimes were also similar in this regard. Therefore, we have not evidence to accept the hypothesis that the Patagonian $\mathrm{Cy}$ press genetic pool is adapted to local optima. Rather this species appears to be phenotypically plastic, at least regarding early traits relative to above ground growth vigour.

The moderate to high estimated $C V_{A}$ for the traits concerning branch development would be indicative of good adaptive potential of A. chilensis natural populations and genetic improvement potential of the species with regards to these traits. These are wanted features considering the intention of domesticating this species to commercial plantations and in view of the current global climate-change scenario. However, inflation of $C V_{A}$ values due to maternal effects should be considered. At early stages of development, the similarity among half-sibs could be deeply influenced by non-genetic features (Roach and Wulff, 1987). Unfortunately, the dioecious condition of this conifer impedes reciprocal crosses, which is the common procedure to test maternal effects. Therefore, these results should at least be confirmed at more advanced ages, that is, when maternal effects are considered to be diluted.
Finally, evidence was presented supporting that early traits relative to the main axis size would be not adaptively meaningful. This additional result should be taken into account for future studies.

Acknowledgements: We gratefully thank Priscila M. Willems and Eduardo P. Cappa for their helpful guidance in the statistical labyrinth. Alejandro Aparicio must also be mentioned for his help with the $\mathrm{R}$ graphics. Comments and literature suggestions by one anonymous reviewer are most appreciated. Seed collection and seedling production were funded by PIA 02/01, Proyecto Forestal de Desarrollo, SAGPyA "Selección para productividad y resistencia a la sequía en poblaciones marginales de Ciprés de la Cordillera". The study was partly supported by Fundación BBVA "Fragmentación y conservación de recursos genéticos de coníferas".

\section{REFERENCES}

Bower A.D. and Aitken S.N., 2008. Ecological genetics and seed transfer guidelines for Pinus albicaulis (Pinaceae). Am. J. Bot. 95: 66-76.

Cavender-Bares J. and Bazzaz F.A., 2002. Changes in drought response strategies with ontogeny in Quercus rubra: implications for scaling from seedlings to mature trees. Oecologia 124: 8-18.

Conifer Specialist Group, 1998. Austrocedrus chilensis. In: IUCN 2006. 2006 IUCN Red List of Threatened Species, www.iucnredlist.org, Downloaded on 31 August 2007.

Cordon V., Forquera J., and Gastiazoro J., 1993. Estudio microclimático del área cordillerana del sudoeste de la Provincia de Río Negro "cartas de precipitación". Universidad Nac. del Comahue, Argentina, $19 \mathrm{p}$.

Cregg B.M., 1994. Carbon allocation, gas exchange, and needle morphology of Pinus ponderosa genotypes known to differ in growth and survival under imposed drought. Tree Physiol. 14: 883-898.

Falconer D.S. and Mackay T.F., 1996. Introduction to Quantitative Genetics. Longman, New York, 464 p.

Foster G.S., 1986. Trends in genetic parameters with stand development and their influence on early selection for volume growth in loblolly pine. For. Sci. 32: 944-959.

Gallo L., Pastorino M.J., and Donoso C., 2004. Variación en Austrocedrus chilensis (D. Don) Pic. Ser. et Bizzarri (Ciprés de la Cordillera). In: Donoso C., Ipinza R., Premoli A., and Gallo L. (Eds.), Variación intraespecífica en las especies arbóreas de los bosques templados de Chile y Argentina. Editorial Universitaria, Santiago de Chile, pp. 233-252.

Grosfeld J., 2002. Análisis de la variabilidad morfológica y arquitectural de Austrocedus chilensis (D. Don) Pic. Serm. et Bizzarri, Fitzroya cupressoides (Molina) I.M. Johnst., Pilgerodendron uviferum (D. Don) Florin y Cupressus sempervirens L. (Cupressaceae). Tesis doctoral, CRUB-UNComahue, Argentina.

Grosfeld J. and Barthélémy D., 2004. Primary growth and morphological markers of interannual growth limits in Cupressaceae from Patagonia. Bot. J. Linn. Soc. 146: 285-293.

Gyenge J.E., Fernández M.E., Dalla-Salda G., and Schlichter T., 2005. Leaf and whole-plant water relations of the Patagonian conifer Austrocedrus chilensis (D. Don) Pic. Ser. et Bizzarri: implications on its drought resistance capacity. Ann. For. Sci. 62: 297-302.

Houle D., 1992. Comparing evolvability and variability of quantitative traits. Genetics 130: 195-204.

King D.A., 1990. The adaptive significance of tree height. Amer. Nat. 135: 809-828.

Lauteri M., Pliura A., Monteverdi M.C., Brugnoli E., Villani F., and Eriksson G., 2004. Genetic variation in carbon isotope discrimination 
in six European populations of Castanea sativa Mill. originating from contrasting localities. J. Evol. Biol. 17: 1286-1296.

Leinonen T., O'Hara R.B., Cano J.M., and Merilä J., 2008. Comparative studies of quantitative trait and neutral marker divergence: a metaanalysis. J. Evol. Biol. 21: 1-17.

López R., Zehavi A., Climent J., and Gil L., 2007. Contrasting ecotypic differentiation for growth and survival in Pinus canariensis. Aust. J. Bot. 55: 759-769.

Lynch M. and Walsh B., 1998. Genetics and Analysis of Quantitative Traits. Sinauer Associates, Sunderland Massachusetts, 980 p.

McKay J.K. and Latta R.G., 2002. Adaptive population divergence: markers, QTL and traits. Trends Ecol. Evol. 17: 285-291.

Merilä J. and Crnokrak P., 2001. Comparison of genetic differentiation at marker loci and quantitative traits. J. Evol. Biol. 14: 892-903.

Moles A.T. and Westoby M., 2004. Seedling survival and seed size: a synthesis of the literature. J. Ecol. 92: 372-383.

Namkoong G., Usanis R.A., and Silen R.R., 1972. Age-related variation in genetic control of height growth in Douglas-fir. Theor. Appl. Genet. 42: 151-159.

Namkoong G. and Conkle M.T., 1976. Time trends in genetic control over height growth in ponderosa pine. For. Sci. 22: 2-12.

Notivol E., García-Gil M.R., Alía R., and Savolainen O., 2007. Genetic variation of growth rhythm traits in the limits of latitudinal cline in Scots pine. Can. J. For. Res. 37: 540-551.

O’Neill G., Adams T.W., and Aitken S.N., 2001. Quantitative genetics of spring and fall cold hardiness in seedlings from two Oregon populations of coastal Douglas-fir. For. Ecol. Manage. 149: 305-318.

Pastorino M.J. and Gallo L.A., 2002. Quaternary evolutionary history of Austrocedrus chilensis, a cypress native to the Andean-Patagonian Forest. J. Biogeogr. 29: 1167-1178.

Pastorino M.J., Gallo L.A., and Hattemer H.H., 2004. Genetic variation in natural populations of Austrocedrus chilensis, a cypress of the Andean-Patagonian Forest. Bioch. Syst. Ecol. 32: 993-1008.

Pastorino M.J. and Gallo L.A., 2006. Mating system in a low-density natural population of the dioecious wind-pollinated Patagonian Cypress. Genetica 126: 315-321.
Pastorino M.J. and Gallo L.A., 2009. Preliminary operational genetic management units of a highly fragmented forest tree species of southern South America. For. Ecol. Manage. 257: 2350-2358.

Puntieri J., Barthélémy D., Martinez P., Raffaele E., and Brion C., 1998. Annual-shoot growth and branching patterns in Nothofagus dombeyi (Fagaceae). Can. J. Bot. 76: 673-685.

$R$ Development Core Team, 2008. $R$ : a language and environment for statistical computing. $R$ Foundation for Statistical Computing, Vienna, Austria. http://www.R-project.org.

Reich P.B., Wright I.J., Cavender-Bares J., Craine J.M., Oleksyn J., Westoby M., and Walters M.B., 2003. The evolution of plant functional variation: traits, spectra, and strategies. Int. J. Plant Sci. 164: 143-164.

Roach D.A. and Wulff R.D., 1987. Maternal effects in plants. Ann. Rev. Ecol. Syst. 18: 209-235.

SAS Institute Inc., 1989. SAS/STAT ${ }^{\circledR}$ User's Guide, Version 6, SAS Institute Inc., Cary, NC.

Seiwa K. and Kikuzawa K., 1991. Phenology of tree seedlings in relation to seed size. Can. J. Bot. 69: 532-538.

Squillace A.E., 1974. Average genetic correlation among offspring from open-pollinated forest trees. Silvae Genet. 23: 149-156.

Sokal R.R. and Rohlf F.J., 1981. Biometry: the principles and practice of statistics in biological research. Freeman, 2nd ed., San Francisco, $875 \mathrm{p}$.

Spitze K., 1993. Population structure in Daphnia obtusa: quantitative genetic and allozyme variation. Genetics 135: 367-374.

Via S. and Lande R., 1987. Genotype - environment interaction and the evolution of plasticity. Evolution 39: 505-522.

Visscher P.M., 1998. On the sampling variance of intraclass correlations and genetic correlations. Genetics 149: 1605-1614.

Whiteley R.E., Black-Samuelsson S., and Jansson G., 2003. Within and between population variation in adaptive traits in Ulmus laevis, the European white elm. For. Genet. 10: 309-319.

Wright S., 1978. Evolution and the genetics of populations, Vol. 4, Variability within and among natural populations. University of Chicago Press, Chicago, 590 p. 